How to cite:

Kazimierczak J. \& Kosmowski P. (2017) In the shadow of the urban

regeneration megaproject: Urban transitions in downtown Łódź,

Poland, Urban Development Issues, vol. 56, pp. 41-52

DOI: $10.2478 /$ udi-2018-0011

URBAN ISSUES

\#urban regeneration \#urban (re)development megaproject neighbourhoods \#spatio-functional changes in the downtown \#descriptive case study \#Łódź \#Poland

\title{
In the shadow of the urban regeneration megaproject: Urban transitions in downtown Łódź, Poland
}

Jarosław Kazimierczak*

University of Lodz

Faculty of Geographical Sciences

Institute of Urban Geography

and Tourism Studies

jaroslaw.kazimierczak@geo.uni.lodz.pl

Piotr Kosmowski

University of Lodz

Faculty of Geographical Sciences Institute of Urban Geography and Tourism Studies

\section{Abstract}

The Nowe Centrum Łodzi project that was completed in 2007 in Łódź, Poland is one of the biggest contemporary large-scale urban (re)development projects in Europe and the largest project of this type in Central Europe. The principal goals of the mega-project in question include the regeneration of degraded post-industrial and post-railway land in the city centre of Łódź and the enhancement of competitiveness and the metropolitan position of the city. The authors seek to identify spatial and functional changes at a mezo-scale, i.e. in the so-called immediate neighbourhood of the urban regeneration megaproject (URMP), which have accompanied the implementation of the Nowe Centrum Łodzi project over the years 2013-2016. The other aim was to classify urban areas neighbouring the URMP based on features of spatial and functional transformation identified in these areas. The studies allowed the researchers to identify three categories of urban area in the immediate neighbourhood of the URMP which revealed differences in spatial and functional transformations. We indicated that the transformation of the immediate neighbourhood of the URMP involved not only the local authorities responsible for the overall improvement of the quality of public space but also other users, inter alia, residents, local urban activists, the business community, public institutions, and NGOs, that in most cases complemented efforts initiated by the Municipality. From the methodological point of view the authors use a case study including desk research, an urban planning inventory, and direct observation.

submitted: October 2017

reviewed: January 2018

accepted: March 2018

(C) 2017 Jarosław Kazimierczak and Piotr Kosmowski. This is an open access article licensed under the Creative Commons Attribution-NonCommercial-NoDerivs License (http:// creativecommons.org/licenses/by-nc-nd/3.0/) 


\section{Urban regeneration megaprojects: their essence and role in urban transitions}

Urban regeneration is a planned process designed to economically and socially reinvigorate degraded urban areas through a series of spatial and functional transformations (Kaczmarek \& Marcińczak 2013; Roberts \& Sykes 2008; Rodríguez, Martínez \& Guenaga 2001). The complexity of urban regeneration requires that infrastructure (hard) projects take account of social and economic aspects and activities (Dixon, Otsuka \& Abe 2011; Moulaert, Salin \& Werquin 2001). According to numerous scholars, urban regeneration can be considered as (a part of) a large-scale project or, in other words, megaprojects (MPs) (e.g. Lehrer \& Laidley 2008; Menez 2006; Olds 2001; Theurillat \& Crevoisier 2014). As a result, urban regeneration megaprojects (URMPs) were distinguished. For the purpose of this study we will follow F. D. Orueta \& S. Fainstein (2008), who define them as projects: a) whose location is determined by the presence of areas which necessitate territorial restructuring due to the loss of their previous uses in the spatio-functional structure of the city; b) where succession of functions occurs following regeneration, which produces a new mixed-use neighbourhood; c) which meet market demand as locations for new office space, tourist and leisure services; and d) whose future economic viability is based on a new method of financing that combines public and private resources in a public-private partnership arrangement. According to P. Le Galès (1995), the URMPs relevance has been on the rise (since the 1980s) as a result of a consistent shift from comprehensive urban planning development towards the implementation of individual strategic projects. P. Lecroart \& J. Palisse (2007) claim that contemporary URMPs have, first and foremost, an architecture and city planning flavour but they also aim to mobilise social and economic development (Theurillat \& Crevoisier 2013). In most cases they address degraded urban areas, usually post-industrial, former ports, docks or railway stations, which according to B. Frantál et al. (2013), P. Lorens (2005) as well as F. D. Orueta \& S. Fainstein (2008) are highly susceptible to metropolitan functions. Despite the fact that a significant share of URMPs has been developed in North America and Western Europe, M. Ouředníček, M. Šimon \& M. Kopečná (2015) underline their essential role as a type of avenue for re-urbanisation in post-socialist Europe.

Regeneration is also an essential part of reurbanisation in Poland, especially in the context of the significant degradation of Polish cities. As in other post-communist $\mathrm{CEE}$ countries, the aim of urban regeneration is to catch up after decades of underdevelopment of the economic and communal capital (Majer 2014; Nowakowski 2013), which would be not possible without EU funding (Pawlak
2011). Z. Ziobrowski \& B. Domański (2010) estimated that 120,000 ha, that is $22 \%$ of urban areas in Polish cities, are run-down and need to be regenerated immediately. Among them, 52\% are historic downtowns and $12 \%$ are post-war housing estates dominated by blocks of flats. Additionally, the same research shows that $20 \%$ of degraded areas in Polish cities are post-industrial areas. An essential part of these post-industrial areas are located in the downtowns, especially in those cities which had grown rapidly in the 19th century as a result of intensive industrialisation, including Łódź and the Silesian cities. One of the key obstacles in regenerating post-industrial sites under the legal and financial conditions in Poland is their disordered ownership status. This is a consequence of the nationalisation of industrial plants during the communist period (Domański 2009). In accordance with Polish law, the commune which is responsible for regeneration may only invest in buildings and areas in its possession (Kaczmarek 2015; Kaczmarek \& Marcińczak 2013). However, due to investment attractiveness resulting from a central location and large area (Lorens 2005), they are increasingly the subject of joint public and private investments, especially in the context of EU funds for the redevelopment of brownfield sites.

The desired effect of carrying out the URMP is to mobilise economic and social development not just within the area covered by the remedial programme but also in its immediate vicinity and more distant neighbourhoods (Moulaert, Salin \& Werquin 2001; Rodríguez, Martínez \& Guenaga 2001; Turok 1992). They often constitute a turning point in the development of urban areas, known in the literature as the "Bilbao effect" (Szmytkowska 2016). This goal is usually accomplished over a longer-time horizon, if at all. In a short-term perspective, the balance of positive and negative impacts of an URMP is determined by how the investment is delivered and, by the same token, by the burden involved on the neighbourhood.

The analysis of spatial relationships in a city occupies a special place in the overall landscape of geographical studies. The urban geographical studies conducted so far on urban regeneration projects have demonstrated that the emergence of a new mixed-use neighbourhood modifies the existing spatio-functional relationships or generates new ones, which impact links between the regenerated space and the remaining urban areas. That was identified in the cases of Manchester, Lyon and Łódź, where new central space was created as a result of urban regeneration projects implemented on post-industrial sites (Kazimierczak 2014). From this point of view we may distinguish relations with the immediate neighbourhood made up of areas adjacent to the area covered by the URMP and relations with more distant areas, i.e., with the city or urban region 
(conurbation). Contemporary studies usually focus on the urban impact of such projects, which results from the specificity of urban regeneration and large-scale urban (re-)development projects, e.g. changes in the image, which improve investment, residential and tourist attractiveness, etc. (Salet 2008). These studies cover a time span from several to a dozen or so years following the completion of the project, when it is possible to assess its economic and social outcomes. There are far fewer studies on the impact of URMPs on their neighbourhoods (immediate and more distant) during the implementation of the project (Bassett, Griffiths \& Smith 2002; Mboumoua 2017). This gap in urban studies has inspired the authors of this paper to share the results of their own studies conducted to identify spatial and functional changes in city centres in the immediate vicinity of a post-industrial area covered by an URMP. That is the main objective of the paper. Changes in Łódź were followed over the period of 3 years, from 2013 to 2016, when the area around the URMP experienced a series of difficulties. Moreover, the studies were designed to classify the urban areas neighbouring the URMP based on the features of spatial and functional transformation identified in these areas.

\section{Study area and methodology}

Łódź is the third largest city in Poland according to number of inhabitants $(698,688$ in 2016). At the same time, it is one of the fastest shrinking cities in Europe due to the economic crisis in the 1990s following the systemic transformation in Poland and in other CEE countries. The reasons for the shrinking of the city cannot be attributed to the economic and demographic situation alone but also to the degradation of the central part of the city and low quality of housing available in the nineteenth century buildings in the area. The overall image of Łódź as a city in crisis, which prevailed for many years after the collapse of its industry, resulted in low investment attractiveness compared to other large cities in Poland. In response to the multifaceted crisis in the city, in the early 21 st century its authorities initiated the regeneration of degraded central urban areas. The project coincided with the opportunity to benefit from resources made available by the EU structural funds. By virtue of a Resolution of Łódź City Council adopted in August 2007 the URMP (Rada Miejska w Łodzi 2007) was approved as part of the redevelopment effort under the working name Nowe Centrum Łodzi (NCŁ). The project covers an area of 100 ha in the city centre alongside the railway line that links the Łódź Fabryczna railway terminus station (Fig. 1) with Warsaw. Planned works include the transformation of post-industrial and post-railway space into a multifunctional central urban area, which de facto is expected to become the future city centre. Flagship projects of the NCE include the adaptation of the monumental power and heat generation plant EC-1 to culture-related functions and the construction of an underground railway station Łódź Fabryczna on the location of the demolished terminus at ground level (Fig. 1). The station is the biggest transport hub in the city, integrated with municipal public transport (bus and tramway lines), as well as national and international bus connections.

The area between the NCE and Piotrkowska street, the present city centre, is crucial for the spatio-functional integration of both central areas in Łódź (Kazimierczak 2014). This part of the city centre, fundamental for further coherent development, has been selected by the authors as a subject for in-depth studies. It occupies 42.12 ha and includes 7 blocks in the city centre. To facilitate the presentation of the results, these blocks are marked with the letters from A to G (Figs. 1 and 2a). Blocks F and G, with a total area of 22.49 ha (53.41\% of the total area covered by the research), form an integral part of the initial NCŁ project drafted in 2007 by the Luxembourgish architect Rob Krier. Blocks C, D, and E, an area of 8.96 ha (21.26\% of the total study area), were incorporated into the NCE project in 2012 as an outcome, inter alia, of the urban planning workshop 'Zszywanie miasta' (Sewing the City Together)' organised in 2011. Blocks C, D, E, F, and G make up one of the three functional zones of the NCŁ (Fig. 1). They cover the historic part of the city centre, which was originally planned within a bigger urban structure for industrial Łódź in the years 1825-1828. These blocks, which together form the western zone of the NCŁ project, are built-up with buildings that will be regenerated and then used for housing and services. Blocks A and B extending over an area of 10.67 ha (25.33\% of the research area) are located between the main shopping street of Łódź - Piotrkowska in the east and Kościuszki Alley on the western side.

The area covered by the study is located an equidistant 15 minutes on foot from the two NCŁ flagship projects: the power and heat generating plant EC-1 and the Łódź Fabryczna railway station. According to the Łódź Local Redevelopment Plan for 2007-2013 this part of the city centre (blocks A to $G$ ) belongs to the so called city service centre and remains within the centre of the core metropolitan area, covered by the redevelopment plan co-financed from the EU structural funds in the period 2014-2020. All of the core metropolitan zone has been divided into 20 projects for 55 urban blocks. The number of each area (project) gives information about the sequence of stages in the redevelopment process. Blocks

1. The aim of the workshop was to identify guidelines for integrating the NCŁ area with Piotrkowska Street. Jarosław Kazimierczak - one of the authors of the paper took part in it. 


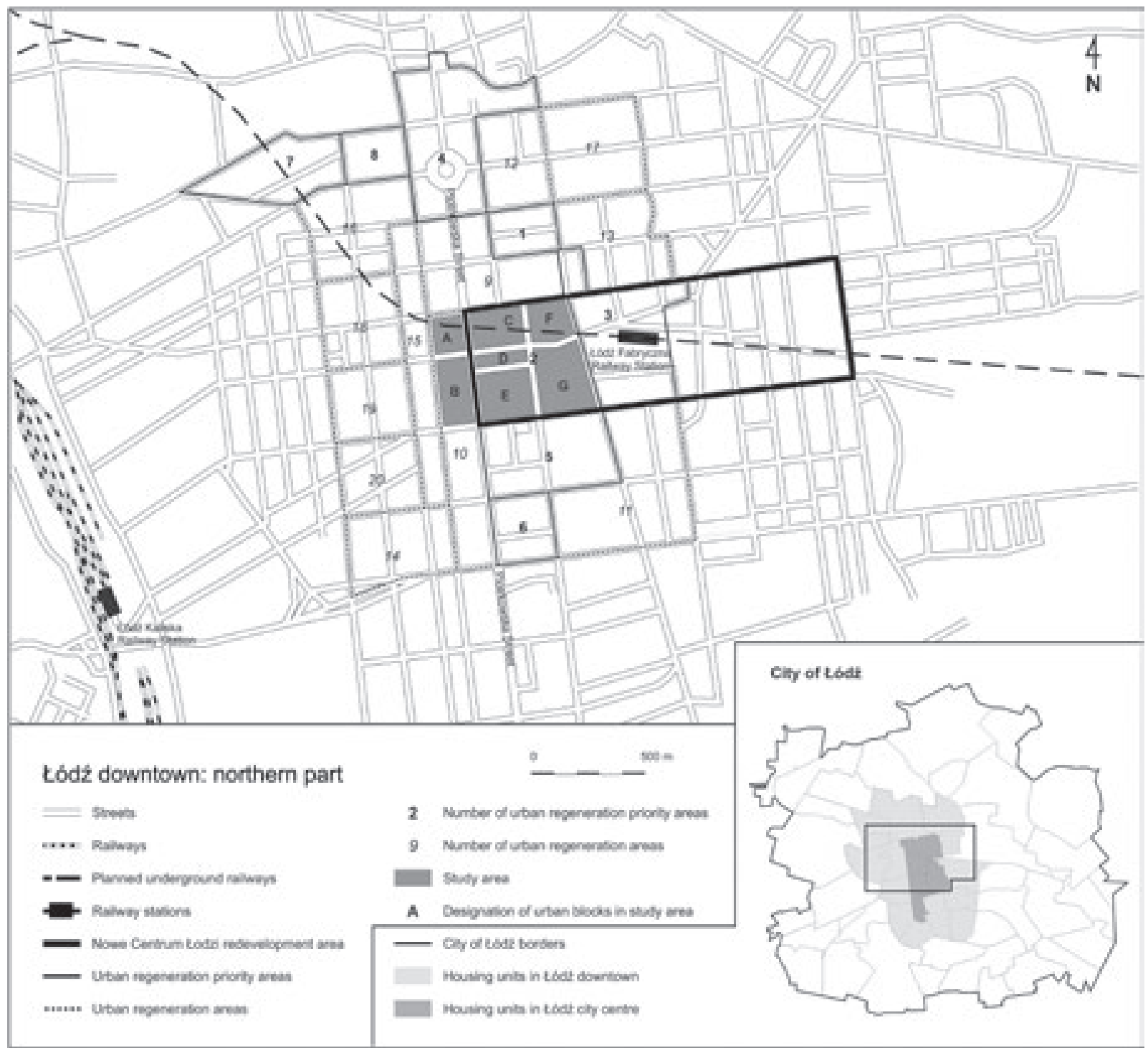

FIGURE 1

Research area and the northern part of Łódź city centre

Source: author's own diagram
C-G are fully included in priority area 2, while blocks A and B are in the centre of the northern and central parts of priority area 10 (Fig. 1). Depending on their historic value, individual buildings within the area included in the study enjoy different types of legal protection. The highest level of protection is accorded to those entered on the register of monuments, which lists 31 buildings (16.2\% of buildings in 2016). Pursuant to Polish legislation, these buildings must not be demolished or modernised without prior notification and the approval of the competent authorities. The Municipal Register of Monuments (Gminna Ewidencja Zabytków - GEZ) includes 90 buildings from the study area (47.1\% of buildings in 2016).

The research method used by the authors is a descriptive case study. According to (Mills, Durepos \& Wiebe 2010: 288) it 'is one that is focused and detailed, in which propositions and questions about a phenomenon are carefully scrutinized and articulated at the outset'. K. R. Yin (2014) adds that its purpose is a description of the phenomenon being analysed in the context of reality. In geographical sciences the case study method includes desk research, an urban planning inventory and direct observation. Field studies, which included making an inventory of buildings in blocks A to G, were conducted in October 2013 and repeated at the turn of March and April 2016. They provided spatial and functional data that help identify the 
TABLE 1

Changes in horizontal and vertical intensity in blocks A-G over the period 2013-2016

Source: own analysis

\begin{tabular}{|c|c|c|c|c|c|c|}
\hline \multirow{2}{*}{ Urban block } & \multicolumn{3}{|c|}{$\mathbf{I}_{\mathrm{H}}$} & \multicolumn{3}{|c|}{$I_{v}$} \\
\hline & 2013 & 2016 & $\Delta_{2013-2016}$ & 2013 & 2016 & $\Delta_{2013-2016}$ \\
\hline$A$ & $42.81 \%$ & $42.81 \%$ & $0.00 \%$ & 3.50 & 3.50 & 0.00 \\
\hline B & $42.29 \%$ & $43.91 \%$ & $1.62 \%$ & 3.44 & 3.52 & 0.08 \\
\hline$C$ & $32.72 \%$ & $32.72 \%$ & $0.00 \%$ & 3.93 & 3.93 & 0.00 \\
\hline $\mathrm{D}$ & $47.91 \%$ & $47.91 \%$ & $0.00 \%$ & 4.00 & 4.00 & 0.00 \\
\hline$E$ & $43.29 \%$ & $43.10 \%$ & $-0.20 \%$ & 3.66 & 3.56 & -0.10 \\
\hline $\mathrm{F}$ & $30.34 \%$ & $30.29 \%$ & $-0.05 \%$ & 5.33 & 4.45 & -0.88 \\
\hline G & $18.55 \%$ & $12.81 \%$ & $-5.75 \%$ & 4.51 & 4.63 & 0.12 \\
\hline$A-G$ & $36.15 \%$ & $35.73 \%$ & $-0.42 \%$ & 3.94 & 3.91 & -0.03 \\
\hline
\end{tabular}

changes that have taken place in the period of the study: morphological, functional and an assessment of the technical status of the buildings. The inventory also included public space, facilities for pedestrians and residents. We used the non-participant observation method to identify similarities and differences in the uses of public space in 2013 and 2016.

\section{Łódź URMP's immediate neighbourhoods short-period-transitions}

The city centre area subject to detailed studies is occupied by blocks representing a low horizontal intensity of development $\left(\mathrm{I}_{\mathrm{H}}\right)$. This rate $\left(\mathrm{I}_{\mathrm{H}}\right)$ is expressed in \% and it is a ratio of the total built-up area in a given block calculated as a sum of the space covered by buildings at their foundations to the total area of the block in question. As demonstrated by J. Kazimierczak (2014), the average horizontal intensity rate of development in blocks in the city centre of Łódź situated alongside Piotrkowska St. from Północna St. in the north to Mickiewicza Av. and Piłsudskiego St. is $76 \%$. In accordance with the classification of urban areas proposed by S. Liszewski (1978) typically used in Polish geographical studies, this rate provides information about the density of development (when horizontal intensity exceeds 75\%). In the blocks A-G forming part of the study the $\mathrm{I}_{\mathrm{H}}$ rate ranges from $12.81 \%$ in block F to $47.91 \%$ in block D (Tab. 1). As a result of morphological transformations that took place within the area examined in the period 2013-2016, $\mathrm{I}_{\mathrm{H}}$ decreased in 3 out of 7 blocks, in the other 3 it remained unchanged and it increased in only 1 block (Tab. 1). Over the whole study area $I_{H}$ decreased from $36.15 \%$ in 2013 to $35.73 \%$ in 2016 .

Over the years 2013-2016 the study area witnessed the demolition of 4 buildings and the construction of 2 new ones. The most profound changes were observed in block G, where two buildings were demolished. The first one was a privately owned tenanted dwelling-house in Kilińskiego St. (Fig. 2b), which de facto collapsed as a result of the demolition of its extensions. Following the demolition of the second building in 2013-2014, the plot was used to build a new Police Station. It is the only new building in block $\mathrm{G}$. In block $\mathrm{E}$ a private-owned town house in Tuwima St., usually tenanted but at that point vacant, was demolished. In the F block the 15-storey Centrum Hotel from the 1970s was demolished at the turn of 2014 and 2015. It was one of the biggest hotels in Łódź. While field studies conducted in 2013 demonstrated that the usually-tenanted dwelling-house in block $\mathrm{E}$ that was demolished was in fact ruined, the elevation of the Centrum Hotel was assessed as complete though neglected and in need of renovation, a description which is not indicative of demolition motivated by poor technical condition. However, the hotel had suffered from financial distress caused by low occupancy rates and this was the reason for demolishing it. Despite the demolition of the Centrum Hotel, the number of hotels in the area covered by the study remained unchanged as in September 2016 a new B\&B-type 2-star hotel opened in block B.

Although the entire area examined represents a very low intensity of horizontal development $\left(I_{H}\right)$ for a European city centre, investment in development projects is not planned in any of the blocks analysed, with the exception of block F (as of December 2016). In block F, with almost the lowest $I_{H}$ rate, five plots owned by the Municipality will be developed within the framework of the regeneration programme. New buildings are intended to fill in the gaps in the frontages of Narutowicza and Sienkiewicza streets. In addition, a private investment project is planned on the plot on which previously had stood the demolished Centrum Hotel.

The demolition and new buildings constructed in blocks B, E, F, and $\mathrm{G}$ have changed their respective vertical intensity development rates $\left(\mathrm{I}_{\mathrm{v}}\right)$ which is an 
FIGURE 2

a) study area; b) morphological changes; c) changes in the condition of buildings; d) buildings by number of floors; e) buildings renovated within the 'Mia100 Kamienic' scheme; f) changes in the number of institutions

Source: own analysis

a)

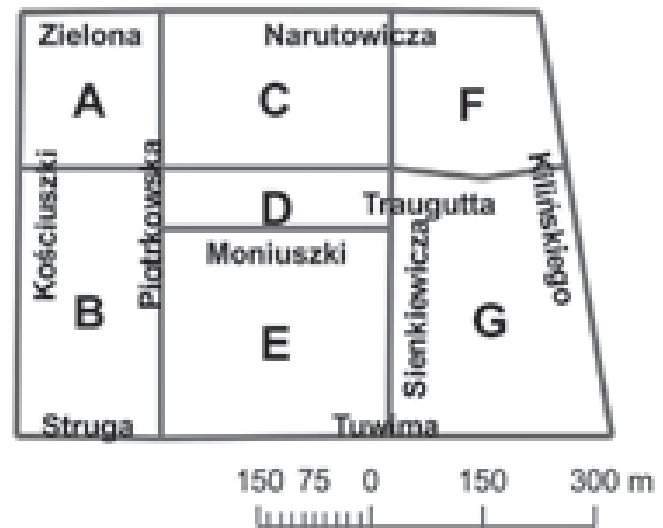

c)

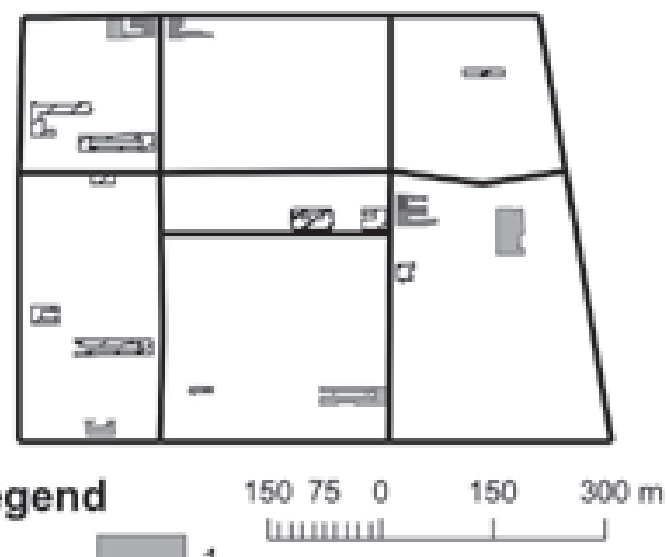

Legend

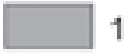

QIIT-2

QII-1 3

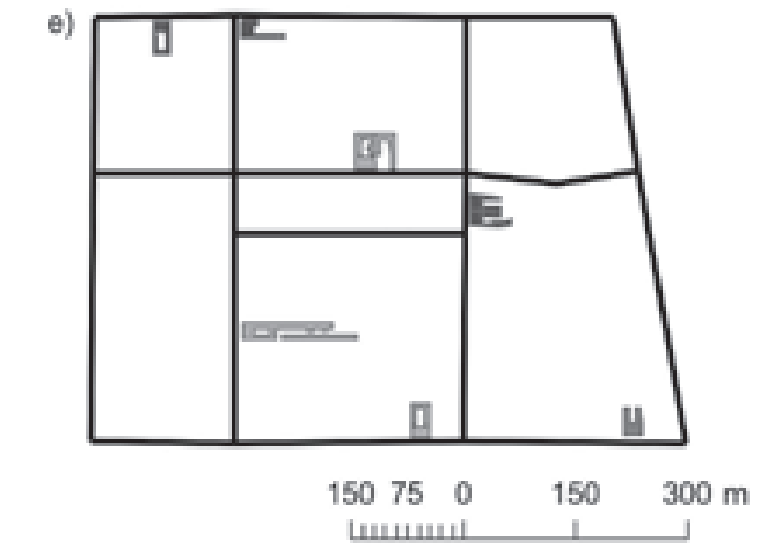

Legend

2012 b)

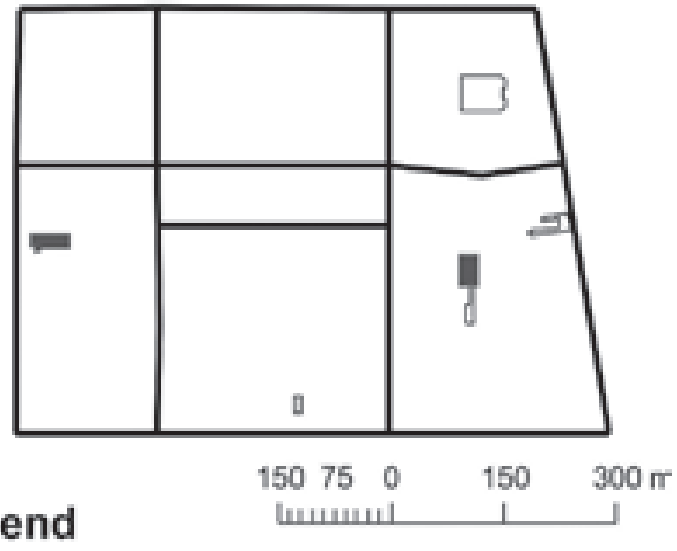

demolished

d)

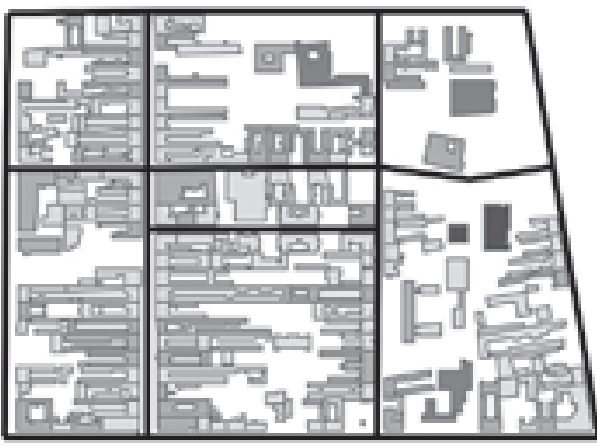

Legend
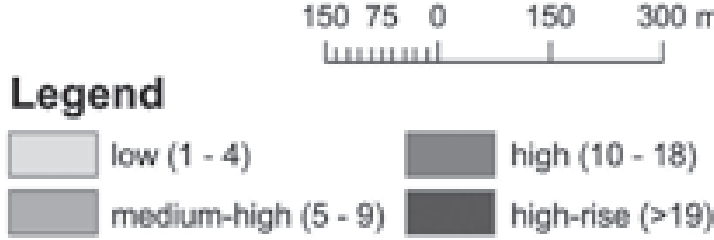

low $(1$ - 4)

medium-high (5 - 9)

high $(10-18)$

high-rise (>19)

f)

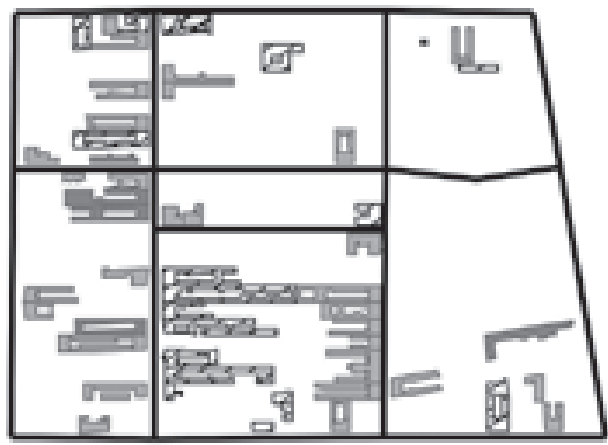

Legend

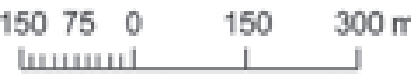

DIT <-3

$1-3$

DVA-3--1 $>3$ 
arithmetic mean of the number of storeys per building in a block; it is calculated as a multiplication of the sum of all floors in a block and the sum of their space at the foundation of buildings. The biggest change involving a decrease of the $I_{v}$ was reported in relation to block $F$ where the Centrum Hotel - one of the highest buildings in this part of the city centre - was demolished. A slight decrease of the $\mathrm{I}_{\mathrm{V}}$ was also observed in the block $\mathrm{E}$, while the rate slightly increased in blocks B and G. Overall, due to morphological changes in all the blocks studied, the $I_{V}$ rate decreased in the area over the years 2013-2016. Yet, the drop was minor (Tab. 1) and, with the exception of block F, almost unnoticeable in the urban landscape (Fig. 2c). According to the classification proposed by S. Liszewski (1978) buildings lower than 2.5-storeys (lower than $11 \mathrm{~m}$ ) are indicative of low vertical intensity of development, while buildings higher than 6 floors (more than $20 \mathrm{~m}$ ) suggest high vertical intensity. Thus, in each of the blocks covered by the study the average height of buildings (ranging from 2.5 to 6 floors or from 11 to 20 $\mathrm{m}$ ) suggests a medium intensity of vertical development $\left(I_{V}\right)$, typical of the majority of cities in Poland.

The studies conducted provide evidence that the intensity of change in $\mathrm{I}_{\mathrm{H}}$ and $\mathrm{I}_{\mathrm{V}}$ rates did not depend on the distance of the neighbouring areas from the URMP. The biggest changes in both rates were observed for blocks $\mathrm{F}$ and $\mathrm{B}$. However, changes in $\mathrm{I}_{\mathrm{H}}$ and $\mathrm{I}_{\mathrm{V}}$ rates were observed in blocks in the immediate neighbourhood of the URMP (F and G), which was not the case of more distant blocks (Tab. 1). That may be indicative of the fluctuating investment attractiveness of the area, in particular when most morphological transformations resulted from the involvement of private operators. Against this backdrop, an act of demolition not followed by new construction projects on vacant (private) plots may be interpreted as a preparatory stage for future commercial investments.

In total $23 \%$ of the real estate in the area examined is fully owned by the Municipality of Łódź. Although in the period covered by the study the Municipality was not involved in morphological changes in any of the above mentioned blocks, it was actively pursuing a refurbishment and major improvement scheme entitled 'Mia100 Kamienic' (City of $10^{2}$ ant Houses) ${ }^{2}$. Pursuant to the Polish legislation in force as of the day of the launching of the scheme, the Municipality could only perform refurbishments in those buildings with regulated ownership status

2. 'Mia100 Kamienic' (City of $10^{2}$ ant Houses) was a modernisation project which has been implemented by Łódź City Council since 2011, The main objective has been to refurbish at least 100 tenanted dwelling houses in Łódź downtown to improve the conditions of living in the downtown. It is only implemented in buildings that are fully owned by Łódź City Council, and it was financed from the Łódź City Budget. and which were fully owned by the Municipality. The area studied includes 44 such tenanted properties but only 9 of them have been covered by the refurbishment scheme. Over the years 2013-2016 improvements were implemented in 5 of them (Fig. 2d). Improved buildings are dispersed over the area examined, which does not help upgrade the quality of the urban landscape. We need to note that the buildings included in the remedial action plan in subsequent years are located relatively close to one another (Fig. 2d).

The field studies conducted in 2013 and 2016 have shown that the condition of buildings improved and houses with elevations assessed as complete and well maintained (CW) accounted for over $41 \%$ of all buildings, compared to 37\% in 2013 (Fig. 3). Only in two blocks had the condition of buildings deteriorated (D and F). That was the effect of demolitions and planned but not yet started refurbishments. The better condition of the real estate (minimum $85 \% \mathrm{CW}$ and $\mathrm{CN}$ ) was identified in blocks situated in the western region of the area examined (A and B) in both studies. The poorer condition of blocks in the immediate proximity of the multimodal Łódź Fabryczna railway station should, in accordance with the plans of the city authorities, significantly improve as a result of redevelopment of the area in question. Positive changes (Fig. 2c) are connected not only with public but also with private investment projects, such as the refurbishment of the tenanted properties in Struga St. (block B) or Sienkiewicza St. (block E) and major improvement of the high rise building in Traugutta St. (block G).

Based on the analysis of the changes in the condition of the elevations of buildings over the period 2013-2016, a derivative of refurbishments undertaken on a minor (from the funds of housing communities or private owners) or major ('Mia100 Kamienic' scheme) scale, we have concluded that the greatest improvement in the technical condition of the buildings and the quality of urban landscape was observed in block $\mathrm{G}\left(\mathrm{I}_{\mathrm{T}}=59.43\right)$. The rate, which describes changes in the condition of buildings $\left(\mathrm{I}_{\mathrm{T}}\right)$ over the years 2013-2016, was calculated as a ratio of sums of the points aggregated for each block and horizontal intensity of development $\left(\mathrm{I}_{\mathrm{H}}\right)$ in each block. In field studies we used a 4-degree evaluation scale for buildings and their elevations. Each positive change in the years 2013-2016 scored +1 point while each negative change scored -1 . The demolition of buildings which degraded the urban landscape scored +4 points, and a new building +5 points. Much less visible improvements than in block $G$ took place in blocks $\mathrm{F}\left(\mathrm{I}_{\mathrm{T}}=15.62\right), \mathrm{E}\left(\mathrm{I}_{\mathrm{T}}=13.21\right), \mathrm{C}\left(\mathrm{I}_{\mathrm{T}}=9.17\right), \mathrm{B}\left(\mathrm{I}_{\mathrm{T}}=6.83\right)$, and $\mathrm{A}\left(\mathrm{I}_{\mathrm{T}}=2.34\right)$. The technical condition of buildings deteriorated in the years covered by the study in block D 
FIGURE 3

Condition of buildings in individual blocks in 2013 and 2016.

Source: authors' research

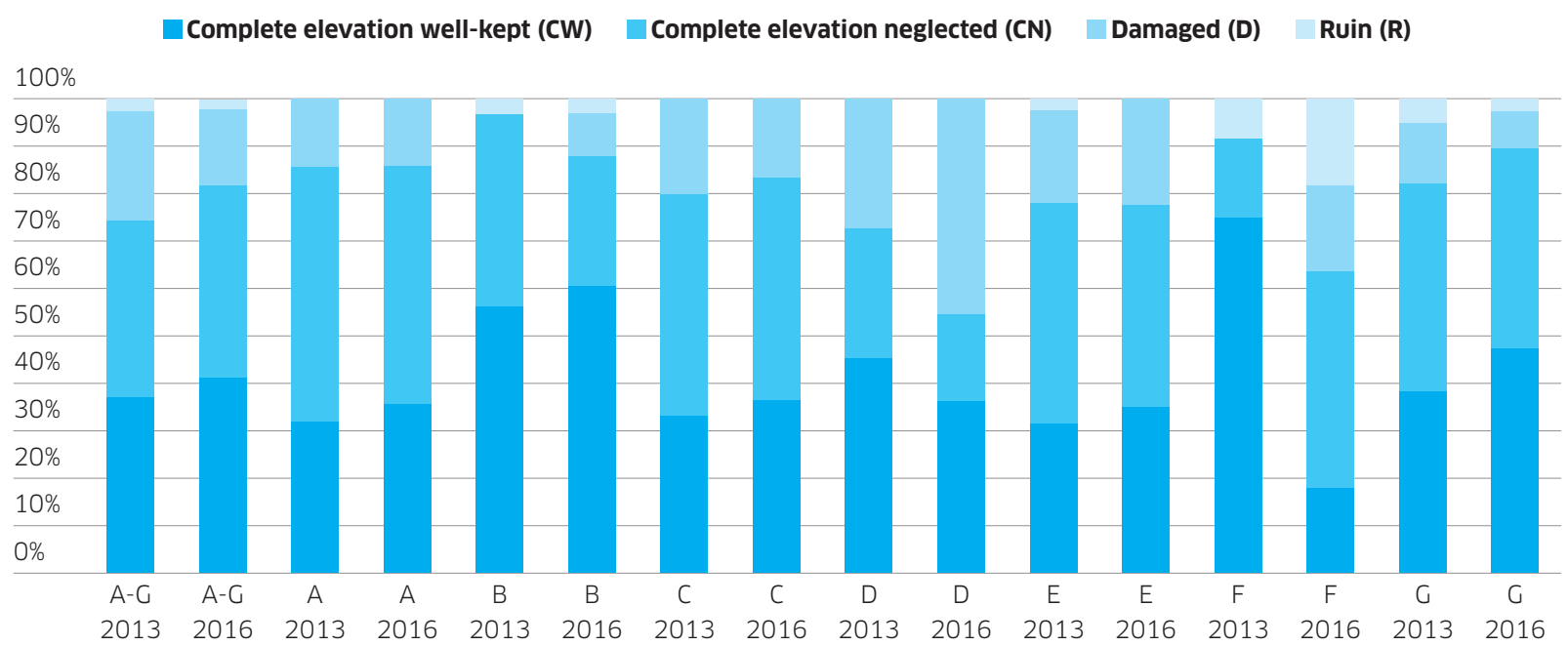

$\left(\mathrm{I}_{\mathrm{T}}=-6.26\right)$, centrally located in relation to the boundaries of the area examined (Fig. 2e). The condition of the elevations of buildings in the block was the poorest even though its neo-Renaissance structures from the 2 nd half of the 19 th century mainly lay alongside Moniuszki St. (a former private street called Ludwik Mayer's Passage with villas of high officials of the Tsar's administration) and represent very high historic value. Investments planned by the Municipality of Łódź, which have been considered in the redevelopment plan for area No. 2, provide for the renovation of vacant and degraded buildings, which will then house the offices of the Department of Culture of the City of Łódź (moved from Piotrkowska St.) and a multimedia library. Redevelopment of area No. 2 includes the refurbishment of 9 buildings from the municipal pool. Another important public investment project in this area provides for the reconstruction of the Łódzki Dom Kultury (Łódź Cultural Centre) in block F. One of the most visible projects in this part of the city centre in recent years was the reconstruction of the highest buildings in Łódź: two 19-storey (68 $\mathrm{m}$ high) office buildings from the 1970s located in block G (Fig. 2c). The refurbishment of the western building was completed in 2012; it was financed from the budget of the Municipality of Łódź and the Marshal's Office of the Łódź Voivodeship. The upgrading of the eastern building was put into operation in 2015. Its modernisation was financed from private funds.

The spatial distribution of buildings in the best technical condition overlaps with the course of Piotrkowska St., lined with the most prominent tenanted properties, which themselves are also an important tourist attraction for the city. It is the most glamorous and the most valuable public space in Łódź, hence special attention is paid to its aesthetics.
Qualitative changes in the area examined in the years 2013-2016 influenced not only the buildings but also the public space. They included: modernisation of the surface of the road, pavement and street furniture in Piotrkowska St. completed in 2014 and the woonerfs ${ }^{3}$ adopted in parts of 6-Sierpnia and Traugutta streets (Fig. 4). Both ideas to transform regular streets into woonerfs were presented as community initiatives and subjected to voting in successive versions of the Citizen Budget. Vast citizen support for both projects encouraged the city authorities to propose a new woonerf in Moniuszki St. However, in 2015 the City Council postponed voting on the project until the refurbishment of buildings in this street is completed. The modernisation is part of the redevelopment of the city centre. Woonerfs in 6-Sierpnia, Traugutta, and Moniuszki streets are crucial to the full integration of Piotrkowska St. with the NCŁ. It was one of the principal postulates of the workshop 'Zszywanie miasta' organised in 2011. Another example of a project delivered under the Citizen Budget (2015) in the area analysed is a playground for children located in an empty lot on the corner of Traugutta and Sienkiewicza streets (block D). It supplements the woonerf in Traugutta St. (Fig. 4).

The modernisation of public space in the centre of Łódź and in the area in question also involves NGOs. The most active among them is the Urban Forms Foundations, very much visible in the city. It initiated the Mural Gallery of wall murals created by artists from all over the world on the walls of buildings in the city centre. In the years 2013-2016 the public space in the area of interest to our study was decorated with 5 new murals. In total there are

3. Woonerf is an idea which originates from Emmen in the Netherlands and consists in slowing the flow of traffic and giving priority to pedestrians. It is a Dutch word meaning premises to reside. 


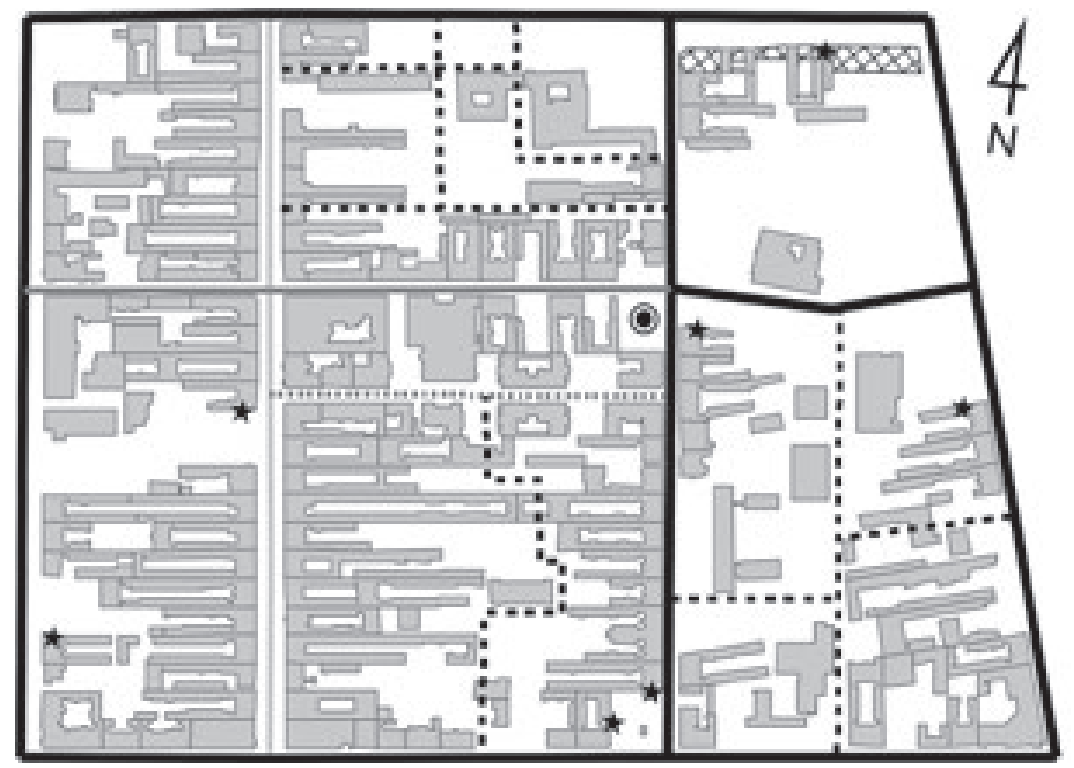

6 murals in all the blocks (Fig. 4). Mural paintings play a significant role in the process of reviving the urban landscape of run-down downtown Łódź, not only in the morphological but also the socio-cultural dimension. As A. Carmo (2011) underlined, this kind of project often materialises acts of collective artistic citizenship and helps in moulding the identity of the citizens.

The reconstruction of Traugutta and 6-Sierpnia streets was a high-speed enterprise and took a dozen or so weeks. Unlike these two investment projects, the redevelopment of Kilińskiego St. on the eastern border of the area in question was much more burdensome to the users. Works conducted from October 2013 changed the layout of the street and separated the tramways from the road traffic. The intention was to calm the traffic in Kilińskiego St. and to improve tramway transport. In the immediate vicinity of the new Łódź Fabryczna railway station and the area covered by the study, two new tramway lines have been added with a big integrated transportation hub for tramway and bus lines. Major improvements in Kilińskiego St. and the emergence of numerous construction sites on its eastern side produced far-reaching consequences for the use of this part of the public space, potentially leading to decreased attractiveness of commercial space alongside the street. The authors of many analyses claimed it should reduce the presence of services in the area, however, we were unable to positively validate the thesis. Nevertheless, our observations confirmed a significant outflow of everyday users of the space (passers-by and potential customers of local businesses). A material change in the population of economic operators was confirmed especially for block E (Fig. 2f). It was connected with an increased number of businesses along the western frontage of Sienkiewicza St. That might be due to the improved attractiveness of the street after part of the traffic from the closed Kilińskiego St. was transferred there. The outflow of business from the eastern frontage of Piotrkowska St. (E block included) can be explained by redevelopment works that went on in the street for 18 months. Some operators moved out (in particular in blocks A, C, and $\mathrm{E}$ ) because of the refurbishment works in the buildings, including those included in the 'Mia100 Kamienic' scheme. Woonerfs, in turn, attracted more business operators into the neighbourhood of 6-Sierpnia and Traugutta streets. The changes observed in all the blocks examined ranged from the outflow of a maximum of 5 operators to an inflow of not more than 6 businesses.

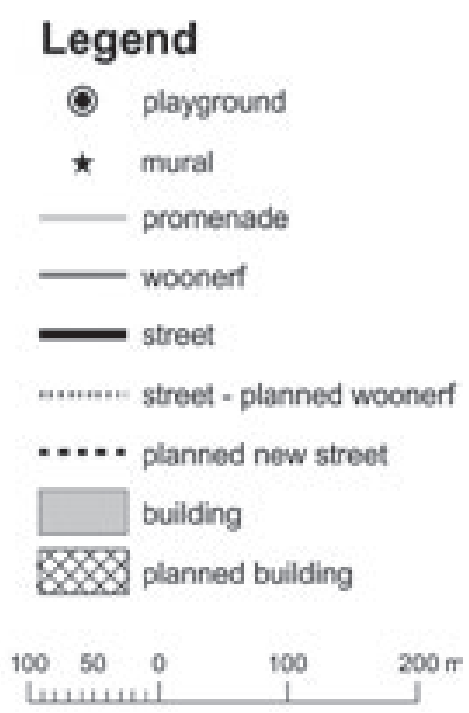

FIGURE 4

Public areas in the blocks examined in 2016 and the changes planned based on the Local Development Plans Source: own analysis 
Categories of NC $€$ neighbourhood transformations

The NC€ project consists of four projects (including the flagship ones) delivered in stages all over the URMP area. Apparently, the distribution of individual investment projects over time alleviates the burden on areas in the city centre adjacent to the URMP. Nevertheless, our studies have revealed some differences in the transformations in the vicinity of the NC€ project. We can divide the blocks covered by our studies into three categories of urban area adjacent to the URMP. The first category includes blocks $\mathrm{F}$ and $\mathrm{G}$ referred to as project areas in the vicinity. These are spaces included in the area transformed within the framework of the NC€ but actually not covered by the investments considered in the Master Plan. Yet, they have been designated as locations for future investment efforts. Spatial and functional transformations in both blocks exhibited: a) the profoundest morphological changes connected with demolition and (planned) new construction, elements which produce the most obvious changes in the urban landscape; $b$ ) the largest scope for technical improvement in buildings; and c) relatively little change in functional facilities. Moreover, block $\mathrm{F}$ is subject to the most significant spatial alterations due to the provision of new pedestrian areas.

The second category comprises blocks $\mathrm{C}, \mathrm{D}$, and $\mathrm{E}$ as non-project areas in the vicinity. These areas are included in the area transformed within the NC€ but no investment listed in the NC€ Master Plan is planned there. In this area a fundamental role is played by tasks that are delivered or planned as part of development operations in the city centre. These operations are complementary to the NC€ project, which is the priority included in priority area No. 2 . The following can be stated about the transformations that took place in all blocks in the period 2013-2016: a) the scope of the morphological changes was unknown; b) they attracted the biggest number of urban investment projects intended to improve the technical condition of buildings; and c) they produced the most profound functional changes. At the same time the area is the site for the largest proportion of public investment projects which determine the character of new public space (woonerfs and new pedestrian routes inside the blocks).

The third category includes blocks A and B as the proper neighbouring area. These blocks are not included in the area transformed under the URMP but they are situated in the immediate vicinity of the NC€ sensu stricto. They exhibit: a) little scope for morphological change like the second category area; b) a deteriorated technical condition of the buildings; and c) functional stability. The analysis of urban investment projects (only one tenanted property was covered by the 'Mia100 Kamienic' scheme and there was a lack of new investment in public areas, with the exception of the woonerf in 6-Sierpnia) reflects a low priority for change in this area, which may be due to its distance from the NCE.

Based on the studies conducted, we may conclude that the deepest spatio-functional changes over the period 2013-2016 took place in the non-project areas in the vicinity of the NCŁ (second category). It may be indicative of the specific susceptibility of this very area to the impact of the NCŁ project and the key role the area plays in the integration of the historic downtown area and the new city centres in Łódź developed on regenerated post-industrial sites (Kazimierczak 2014), which suggests a series of investment interventions of the Municipality.

\section{Conclusions}

Studies conducted in Łódź have shown that central areas in the part of the city neighbouring the URMP with the working name of Nowe Centrum Łodzi are subject to very dynamic spatial and functional transformations. This is also suggested by the scope of spatio-functional changes identified within the short-term analysis. The relevance of functional transformations of the urban space in question was secondary compared to spatial transformations. Some of them were planned and resulted from the assumptions of the Local Development Plans No. 72 (blocks A-E) and No. 85 (blocks F and G) like, e.g., demolitions or refurbishment in tenanted properties owned by the Municipality of Łódź. Some were unplanned and spontaneous, e.g., the woonerfs created on the initiative of the local community (Citizen's Budget) or new murals in the public space. Based on the studies, we may conclude that the transformation of the immediate neighbourhood of the URMP involved not only the local authorities responsible for the overall improvement of the quality of public space but also other users, inter alia, residents, local urban activists, the business community, public institutions, and NGOs. Based on the Estonian example, J. Tinterra et al. (2014), show a common perception that brownfield redevelopment, including post-industrial urban areas in post-socialist cities, is a private sector issue, while the results of our research illustrate strong public commitment. We need to stress that the actions undertaken by all of these city actors in most cases complemented efforts initiated by the Municipality. From this perspective, the city authorities should be praised for taking social initiatives into consideration. This was also a conclusion from T. Fenster \& T. Kulka's (2016) research, who suggested a new take for planners and mediators on the process of working with a community, one which emphasises the nuanced relations between various types of knowledge, rather 
than a dichotomy between professional and local, powerful and powerless.

Another cluster of transformations, mainly functional ones, may be described as repercussions of the burden involved in urban investment projects such as, e.g., the redevelopment of roads and pavements (the case of Piotrkowska St.) and the refurbishment of tenanted dwelling-houses. An investment project delivered in the area of the NCE covered by the URMP exerted a much smaller impact than initially expected by the authors. This may be attributed to investment projects in blocks C-G planned by the Municipality as part of the redevelopment project for the city centre in the period 2014-2020 (priority area No. 2) co-financed with EU structural funds. To entrepreneurs such plans may be a credible message which promises an improvement in

\section{REFERENCES}

Bassett, K., Griffiths, R. \& Smith., I. (2002) Testing Governance: Partnership, planning and conflict in waterfront regeneration, Urban Studies, 39(10), 1757-1775.

Carmo, A. (2011) Revolutionary landscapes: the PCTP/MRPP mural paintings in the Lisbon metropolitan areas, Finisterra, XLVI (92), 25-41.

Dixon, T., Otsuka, N. \& Abe., H. (2011) Critical success factors in urban brownfield regeneration: an analysis of 'hardcore' sites in Manchester and Osaka during the economic recession (2009-10), Environment and Planning A, 43, 961-980.

Domański, B. (2009) Rewitalizacja terenów poprzemysłowych - specyfika wyzwań i instrumentów, [in:] W. Jarczewski, ed., Przestrzenne aspekty rewitalizacji - śródmieścia, blokowiska, tereny poprzemysłowe, pokolejowe i powojskowe, Instytut Rozwoju Miast, Kraków, 125-137 [in Polish].

Fainstein, S. (2008) Mega-projects in New York, London and Amsterdam, International Journal of Urban and Regional Research, 32(4), 768-85.

Fenster, T. \& Kulka, T. (2016) Whose knowledge, whose power? Ethics in urban regeneration projects with communities, Geografiska Annaler: Series B, Human Geography, 98(3), 221-238.

Frantál, B., Kunc, J., Nováková, E., Klusáček, P., Martinát, S. \& Osman, R. (2013) Location matters! Exploring brownfields regeneration in a spatial context (case study of the South Moravian Region, Czech Republic), Moravian Geographical Reports, 21(2), 5-19.

Kaczmarek, S. \& Marcińczak, S. (2013) The blessing in disguise: Urban regeneration in Poland in a neo-liberal milieu, [in:] M.E. Leary, J. McCarthy, eds., The Routledge companion to urban regeneration, Routledge Taylor \& Francis Group, London and New York, 98-106.

Kaczmarek, S. (2015) Skuteczność procesu rewitalizacji. Uwarunkowania, mierniki, perspektywy, Studia Miejskie, 17, 27-37 [in Polish].

Kazimierczak, J. (2014) Wpływ rewitalizacji terenów poprzemysłowych na organizacje przestrzeni centralnej w Manchesterze, Lyonie $i$ Łodzi, Wydawnictwo Uniwersytetu Łódzkiego, Łódź [in Polish].

Le Galès, P. (1995) Du gouvernement des villes à la gouvernance urbaine, Revue française de science politique, 45(1), 57-95 [in French]. Lecroart, P. \& Palisse, J. (2007) Large-scale urban development projects in Europe: what lessons can be learnt for the Île-de-France Region?, Les Cahiers, 145, 5-28. their working environment in the near future and motivates them to stay despite some burdens and the outflow of some users of the public space (the case in Kilińskiego St.). These entrepreneurs are often motivated by the future vicinity of the new city centre, which will make their present location more prestigious. Hence, using Łódź as an example we may positively validate the thesis formulated in the literature, according to which URMP exerts a positive impact upon its immediate neighbourhood. Our studies demonstrate that such an impact can also be identified when an URMP is being implemented.

\section{Acknowledgements}

This paper is financed by National Science Centre, Poland based on decision DEC-2011/03/N/HS4/03145 and no. DEC-2014/15/B/HS4/01940.

Lehrer, U. \& Laidley, J. (2008) Old Mega-Projects Newly Packaged? Waterfront Redevelopment in Toronto, International Journal of Urban and Regional Research, 32(4), 786-803.

Liszewski, S. (1978) Tereny miejskie. Podział i klasyfikacja, Acta Universitatis Lodziensis, Nauki Matematyczno-Przyrodnicze, Folia Geographica, II, 15, 3-30 [in Polish].

Lorens, P. (2005) Wstępna typologia obszarów zdegradowanych o funkcjach i potencjale metropolitalnym, Biuletyn KPZK PAN, 223, 57-74 [in Polish].

Majer, A. (2014) Odrodzenie miast, Wydawnictwo Uniwersytetu Łódzkiego \& Wydawnictwo Naukowe Scholar, Łódź-Warszawa [in Polish].

Mboumoua, I. (2017) Revisiting the growth coalition concept to analyse the success of the Crossrail London megaproject, European Planning Studies, 25(2), 314-331.

Menez, F. (2006) Le territoire au cœur des rapports publics privés: La cite internationale de Lyon, Géocarrefour, 81(2), 105-111 [in French].

Mills, A., Durepos, G., Wiebe, E., eds., (2010) Encyclopedia of Case Study Research, Sage, CA.

Moulaert, F., Salin, E. \& Werquin, T. (2001) Euralille: Large-Scale Urban Development and Social Polarization, European Urban and Regional Studies, 8(2), 145-160.

Nowakowski, M. (2013) Sto lat planowania przestrzeni polskich miast (1910-2010), Oficyna Naukowa, Warszawa [in Polish].

Olds, K. (2001) Globalization and Urban Change: Capital, Culture, and Pacific Rim Mega-Projects, Oxford Geographical and Environmental Studies, Oxford University Press, Oxford.

Orueta, F. D. \& Fainstein, S. (2008) The New Mega-Projects: Genesis and Impacts, International Journal of Urban and Regional Research, 32(4), 759-767.

Ouředníček, M., Šimon, M. \& Kopečná, M. (2015) The reurbanisation concept and its utility for contemporary research on post-socialist cities: The case of the Czech Republic, Moravian Geographical Reports, 23(4), 26-35.

Pawlak, A. (2011) Działania przestrzenne w programach rewitalizacji obszarów miejskich - wybrane przykłady małych miast małopolski, Czasopismo Techniczne. Architektura 1-A/2011, 10, 87-93 [in Polish]. 
Rada Miejska w Łodzi (2007) Uchwała Nr XVII/279/07 Rady Miejskiej $w$ Łodzi $z$ dn. 28 sierpnia 2007 w sprawie przyjęcia Programu Nowe Centrum Łodzi, Łódź [in Polish].

Roberts, P. \& Sykes, H. (2008) Urban Regeneration: A handbook, Sage, Los Angeles-London-New Dehli-Singapure-Washinton DC. Rodríguez, A., Martínez, E. \& Guenaga, G. (2001) Uneven Redevelopment: New Urban Policies and Socio-Spatial Fragmentation in Metropolitan Bilbao, European Urban and Regional Studies, 8(2), $161-178$.

Salet, W. (2008) Rethinking Urban Projects: Experiences in Europe, Urban Studies, 45(11), 2343-2363.

Szmytkowska, M. (2016) Realizacje urbanistyczne w mieście postindustrialnym i ich wpływ na kształtowanie ładu przestrzennego, Studia Miejskie, 22, 9-22 [in Polish].

Theurillat, T. \& Crevoisier, O. (2013) The Sustainability of a Financialized Urban Megaproject: The Case of Sihlcity in Zurich, Interna- tional Journal of Urban and Regional Research, 37(6), 2052-2073.

Theurillat, T. \& Crevoisier, O. (2014) Sustainability and the Anchoring of Capital: Negotiations Surrounding Two Major Urban Projects in Switzerland, Regional Studies, 48(3), 501-515.

Tintěra, J., Ruus, A., Tohvri, E. \& Kotval, Z. (2014) Urban brownfields in Estonia: scope, consequences and redevelopment barriers as perceived by local governments, Moravian Geographical Reports, 22(4): 25-38.

Turok, I. (1992) Property-Led Urban Regeneration: Panacea or Placebo?, Environment and Planning A, 24(3), 361-379.

Yin, K. R. (2014) Case Study Research: Design and Methods, Sage, London-New Delhi.

Ziobrowski, Z. \& Domański, B. (2010) Rewitalizacja miast polskich jako sposób zachowania dziedzictwa materialnego i duchowego oraz czynnik zrównoważonego rozwoju. Podsumowanie projektu, Instytut Rozwoju Miast, Kraków [in Polish]. 